\title{
CD Antigens 2001
}

David Mason, Pascale André, Armand Bensussan, Chris Buckley, Curt Civin, Edward Clark, Masja de Haas, Sanna Goyert, Martin Hadam, Derek Hart, Václav Hořejší, Stefan Meuer, James Morrissey, Reinhard Schwartz-Albiez, Stephen Shaw, David Simmons, Mariagrazia Uguccioni, Ellen van der Schoot, Eric Vivier, Heddy Zola

Haematology Department (DM), John Radcliffe Hospital, Oxford, United Kingdom; Centre d'Immunologie (PA, EV), INSERM-CNRS de Marseille Luminy, Marseille, France; INSERM Institut National de la Santé et de la Recherche Medicale (AB), Creteil, France; Division of Immunity and Infection (CB), MRC Centre for Immune Regulation, Birmingham, United Kingdom; Johns Hopkins Comprehensive Cancer Center (CC), Baltimore, Maryland; Department of Microbiology (EC), University of Washington, Seattle, Washington; CLB (MdH, EvdS), Department of Experimental Immunohematology, Amsterdam, The Netherlands; Laboratory of Molecular Hematology/Division of Molecular Medicine (SG), Cornell University Medical College, Manhasset, New York; Kinderklinik-Medizinische Hochschule (MH), Hannover, Germany; Mater Medical Research Institute, Mater Hospital (DH), South Brisbane, Australia; Institute of Molecular Genetics, (VH) Academy of Sciences of the Czech Republic, Prague, Czech Republic; Institut für Immunologie (SM), Ruprecht-Karls Universität, Heidelberg, Germany; University of Illinois College of Medicine (JM), Urbana, Illinois; German Cancer Research Centre (RS-A), Tumor Immunology, Heidelberg, Germany; National Institutes of Health (SS), Bethesda, Maryland; Celltech R\&D Ltd (DS), Great Abington, Cambridge, United Kingdom; Institute for Research in Biomedicine (MU), Bellinzona, Switzerland; and Child Health Research Institute (HZ), Women's \& Children's Hospital, North Adelaide, SA, Australia

The Tradition of Human Leukocyte Differentiation Antigen Workshops

The process of categorizing the antigenic molecules and epitopes associated with human white cells, via the collaborative study of monoclonal antibodies, dates back to the early 1980s, when the first HLDA (Human Leukocyte Differentiation Antigen) Workshop was held in Paris. This initial meeting listed only 15 agreed molecular entities, but it created an internationally agreed basis for the nomenclature of leukocyte molecules (the CD scheme) and also provided a forum for reporting studies on their function and practical relevance. A further six HLDA meetings have been held since the first Paris meeting. The most recent of these (HLDA7) took place last year in Harrogate, UK, and the proceedings of the meeting will be published later this year (Leucocyte Typing VII, Oxford University Press).
Copyright (C) 2002 by the United States and Canadian Academy of Pathology, Inc.

VOL 15, NO. 1, P. 71, 2002 Printed in the U.S.A.

Date of acceptance: September 27, 2001.

Address reprint requests to: David Y. Mason, Haematology Department, John Radcliffe Hospital, Oxford, OX3 9DU, United Kingdom; e-mail: david.mason@ndcls.ox.ac.uk; fax: 00-44-1865-763272.
The Aims and Approaches of the 7th HLDA Workshop

The Limitations of "Blind" Antibody Screening

It was apparent at the previous meeting, HLDA6, held in Kobe, Japan, in 1996, that the technique of detecting molecular entities by screening coded panels of monoclonal antibodies against human cells was becoming obsolescent. Antibodies to the most immunogenic molecules had already been produced, and fewer laboratories than in the early days were prepared to devote resources to raising new antibodies because the probability of finding novel reagents becomes ever less likely. In consequence, many antibodies in the 6th Workshop were reagents (submitted by laboratories that were not equipped to characterize them) that proved to be of known specificity.

\section{Selection of Antibodies}

With these considerations in mind, the 7th Workshop adopted a different approach: instead of screening poorly characterized antibodies, reagents were selected (and actively solicited) for which at least some molecular data were already available. A substantial number of monoclonal antibodies reactive with leukocyte-associated molecules exist that do not meet the traditional criterion for establishing a new $\mathrm{CD}$ specificity (i.e., the existence of at least two independent antibodies of the same spec- 
TABLE 1. New CD Designations

\begin{tabular}{|c|c|c|c|}
\hline $\begin{array}{c}\mathrm{CD} \\
\text { Designation }\end{array}$ & Name & Section & Locus Link \\
\hline CD15u & Sulphated CD15 & Carbohydrate structures & \\
\hline CD60a & GD3 & Carbohydrate structures & \\
\hline CD60b & 9-O-acetyl-GD3 & Carbohydrate structures & \\
\hline CD60c & 7-O-acetyl-GD3 & Carbohydrate structures & \\
\hline CD75 & Lactosamines & Carbohydrate structures & \\
\hline CD75s & Alpha-2,6-sialylated lactosamines (formerly CDw75 and CDw76) & Carbohydrate structures & \\
\hline CD85 & ILT/LIR family (see Table 2) & Dendritic cells & \\
\hline CD110 & MPL, TPO R & Platelets & 4352 \\
\hline CD111 & PRR1/Nectinl & Myeloid cells & 5818 \\
\hline $\mathrm{CD} 112$ & PRR2 & Myeloid cells & 5819 \\
\hline CD133 & AC133 & Stem/progenitor cells & 8842 \\
\hline CD156b & TACE/ADAM17 & Adhesion structures & 6868 \\
\hline CD158 & KIR family (see Table 2) & NK cells & \\
\hline CD159a & NKG2A & NK cells & 3821 \\
\hline CD160 & BY55 & $\mathrm{T}$ cells & 11126 \\
\hline CD162R & PEN5 & NK cells & 6404 \\
\hline CD167a & Discoidin domain R (DDRl) & Adhesion structures & 780 \\
\hline CD168 & RHAMM & Adhesion structures & 3161 \\
\hline CD169 & Sialoadhesin & Adhesion structures & 6614 \\
\hline CD170 & Siglec-5 & Adhesion structures & 8778 \\
\hline CD171 & L1 & Adhesion structures & 3897 \\
\hline $\mathrm{CD} 172 \mathrm{a}$ & $\operatorname{SIRP} \alpha$ & Adhesion structures & 8194 \\
\hline CD173 & Blood group $\mathrm{H}$ type 2 & Carbohydrate structures & \\
\hline CD174 & Lewis y & Carbohydrate structures & \\
\hline CD175 & Tn & Carbohydrate structures & \\
\hline CD175s & Sialyl-Tn & Carbohydrate structures & \\
\hline CD176 & $\mathrm{TF}$ & Carbohydrate structures & \\
\hline CD177 & NB1 & Myeloid cells & \\
\hline CD178 & Fas ligand & Cytokine/chemokine receptors & 356 \\
\hline CD179a & Vpre-B & $\mathrm{B}$ cells & 7441 \\
\hline CD179b & Lambda 5 & B cells & 3543 \\
\hline CD180 & RP105 & B cells & 4064 \\
\hline CD183 & CXCR3 & Cytokine/chemokine receptors & 2833 \\
\hline CD184 & CXCR4 & Cytokine/chemokine receptors & 7852 \\
\hline CD195 & CCR5 & Cytokine/chemokine receptors & 1234 \\
\hline CDw197 & CCR7 & Cytokine/chemokine receptors & 1236 \\
\hline CD200 & OX2 & Nonlineage molecules & 4345 \\
\hline CD201 & EPC R & Endothelial cells & 10544 \\
\hline CD202b & Tie2 (Tek) & Endothelial cells & 7010 \\
\hline CD203c & NPP3/PDNP3 & Myeloid cells & 5169 \\
\hline CD204 & Macrophage scavenger $\mathrm{R}$ & Myeloid cells & 4481 \\
\hline CD205 & DEC205 & Dendritic cells & 4065 \\
\hline CD206 & Macrophage mannose R & Dendritic cells & 4360 \\
\hline CD207 & Langerin & Dendritic cells & 50489 \\
\hline CD208 & DC-LAMP & Dendritic cells & \\
\hline CD209 & DC-SIGN & Dendritic cells & 30385 \\
\hline CDw210 & IL-10 R & Cytokine/chemokine receptors & $3587 ; 3588$ \\
\hline CD212 & IL-12 R & Cytokine/chemokine receptors & 3594 \\
\hline CD213al & IL-13 R $\alpha 1$ & Cytokine/chemokine receptors & 3597 \\
\hline CD213a2 & IL-13 R $\alpha 2$ & Cytokine/chemokine receptors & 3598 \\
\hline CDw217 & IL-17 R & Cytokine/chemokine receptors & 23765 \\
\hline CD220 & Insulin $\mathrm{R}$ & Nonlineage molecules & 3643 \\
\hline CD221 & IGF1 R & Nonlineage molecules & 3480 \\
\hline CD222 & Mannose-6-phosphate/IGF2 R & Nonlineage molecules & 3482 \\
\hline CD223 & LAG-3 & Nonlineage molecules & 3902 \\
\hline CD224 & $\gamma$-glutamyl transferase & Nonlineage molecules & 2678 \\
\hline CD225 & Leul3 & Nonlineage molecules & 8519 \\
\hline CD226 & DNAM-1 (PTA1) & $\mathrm{T}$ cells & 10666 \\
\hline CD227 & MUC.1 & Nonlineage molecules & 4582 \\
\hline CD228 & Melanotransferrin & Nonlineage molecules & 4241 \\
\hline CD229 & Ly9 & Nonlineage molecules & 4063 \\
\hline CD230 & Prion protein & Nonlineage molecules & 5621 \\
\hline CD231 & TALLA-1/A15 & Nonlineage molecules & 7102 \\
\hline CD232 & VESP R & Nonlineage molecules & 10154 \\
\hline CD233 & Band 3 & Erythroid cells & 6521 \\
\hline CD234 & Fy-glycoprotein (DARC) & Erythroid cells & 2532 \\
\hline CD235a & Glycophorin A & Erythroid cells & 2993 \\
\hline CD235b & Glycophorin B & Erythroid cells & 2994 \\
\hline CD235ab & Glycophorin A/B crossreactive mabs & Erythroid cells & \\
\hline CD236 & Glycophorin C/D & Erythroid cells & \\
\hline CD236R & Glycophorin C & Erythroid cells & 2995 \\
\hline CD238 & Kell & Erythroid cells & 3792 \\
\hline CD239 & B-CAM & Erythroid cells & 4059 \\
\hline CD240CE & Rh30CE & Erythroid cells & 6006 \\
\hline CD240D & Rh30D & Erythroid cells & 6007 \\
\hline CD240DCE & Rh30D/CE cross-reactive mabs & Erythroid cells & \\
\hline CD241 & RhAg & Erythroid cells & 6005 \\
\hline CD242 & ICAM-4 & Erythroid cells & 3386 \\
\hline CD243 & MDR-1 & Stem/progenitor cells & \\
\hline CD244 & 2B4 & NK cells & 51744 \\
\hline CD245 & $\mathrm{p} 220 / 240$ & $\mathrm{~T}$ cells & \\
\hline CD246 & Anaplastic lymphoma kinase & $\mathrm{T}$ cells & 238 \\
\hline CD247 & $\zeta$ chain & $\mathrm{T}$ cells & 919 \\
\hline
\end{tabular}


ificity). This rule dates from the first HLDA Workshop two decades ago: since that time, biochemical and molecular biological techniques for characterizing the targets of new antibodies have come to be widely used. Consequently, it is now considered appropriate to establish a CD designation for a molecule if its gene has been cloned and at least one specific monoclonal antibody has been studied in the Workshop.

\section{New Workshop Sections}

Four new sections were introduced in the 7th HLDA Workshop to add to the traditional list from past meetings: namely, Dendritic Cells, Stem/Progenitor Cells, Erythroid Cells, and Carbohydrate Structures. Although it has been recognized for many years that monoclonal antibodies reactive with human leukocytes can be specific for carbohydrate epitopes (e.g., the carbohydrate CD category CD15 was identified at the first Workshop), they had not received specific attention in any Workshop. The inclusion of erythroid molecules, although it may seem out of place in a "Leukocyte Workshop," was justified by the number of molecules shared between white and red cells (e.g., cytokine receptors) that hint at unexplored functions of red cells.

\section{The Yield of New CD Specificities in the 7th HLDA Workshop}

This more active approach to the identification of new CD specificities represented a break with tradition, but the results justified the new approach because a total of well over 80 new entities were added to the list of CD specificities. This compares favorably with previous Workshops (an average of less than 30 CD specificities per Workshop), and it also largely avoided the laborious screening in multiple laboratories of antibodies that prove to be directed against known CD molecules.

Tables 1 and 2 list the new specificities established at the 7th Workshop. Full details will be found in Leucocyte Typing VII, and molecular, functional, and other data can be found for many of these new specificities on the Website for "Protein Reviews on the Web" (www.ncbi.nlm.nih. gov/prow/).

\section{The Eighth Workshop}

Plans are well advanced for the 8th Workshop, to be organized in Adelaide in 2004 under the aegis of Prof. H. Zola (see www.hlda8.org). It is sometimes assumed that the catalog of surface molecules associated with human hemopoietic cells is now essentially complete, but there is abundant evidence in the literature for novel surface molecules that
TABLE 2. New CD Nomenclature for ILT/LIR and KIR Molecules

\begin{tabular}{ll}
\hline \multicolumn{1}{c}{ CD Designation } & \multicolumn{1}{c}{ Name } \\
\hline The ILT/LIR family & \\
CD85a & ILT5/LIR3 \\
CD85b & ILT8 \\
CD85c & LIR8 \\
CD85d & ILT4/LIR2, MIR10 \\
CD85e & ILT6/LIR4 \\
CD85f & ILT11 \\
CD85g & ILT7 \\
CD85h & ILT1/LIR7 \\
CD85i & LIR6 \\
CD85j & ILT2/LIR1, MIR7 \\
CD85k & ILT3/LIR5 \\
CD85l & ILT9 \\
CD85m & ILT10 \\
The KIR family & \\
CD158z & KIR3DL7/KIRC1 \\
CD158b1 and CD158b2 & KIR2DL2/p58.2 and KIR2DL3/p58.3 \\
CD158a & KIR2DL1/p58.1 \\
CD158c & KIR2DS6/KIRX \\
CD158d & KIR2DL4 \\
CD158e1 and CD158e2 & KIR3DL1/p70 and KIR3DS1/p70 \\
CD158f & KIR2DL5 \\
CD158g & KIR2DS5 \\
CD158h & KIR2DS1/p50.1 \\
CD158i & KIR2DS4/p50.3 \\
CD158j & KIR2DS2/p50.2 \\
CD158k & KIR3DL2/p140 \\
\hline & \\
\hline
\end{tabular}

For further details of this classification, based on the position of the genes on chromosome 19q;13.4 from centromeric to telomeric loci, see André et al. (1).

would merit study at the next Workshop and that could provide the basis for new CD designations. Table 3 comprises a list of potential new molecules reported after the production of monoclonal antibodies and also a more extensive list of surface molecules identified by gene cloning. In most instances, no antibodies are available against the putative new leukocyte/endothelial markers in this latter group. Specific and well-characterized reagents, whether monoclonal or polyclonal, are needed not only for detecting these new "virtual" molecules but also for defining functional domains, for characterizing 3D protein structure, and for analyzing protein-protein interactions. It may be added that cloning of gene sequences often reveals multiple members of new or existing molecular families (e.g., the Toll-like receptors) and may identify surface receptors that bind more than one ligand or vice versa (e.g., the TALL- 1 and APRIL ligands for TACI and BCMA). Furthermore, a number of leukocyte-associated markers have been cloned from mice and other species, and almost all will have human homologues. The 8th Workshop will provide a forum for a range of antibody-based studies relating to this accumulating corpus of genomic and proteomic data.

As in the 7th Workshop, in which four new sections were added, it may be possible to include neuronal cells in the 8th Workshop. Many neuronal 


\begin{tabular}{|c|c|c|c|c|}
\hline Molecule & Molecule Size & Cell Types & Comments & Reference no. \\
\hline \multicolumn{5}{|c|}{ Identified after antibody production } \\
\hline AM-3K antigen & 70 and $120 \mathrm{kDa}$ & Macrophages & & (2) \\
\hline $\begin{array}{l}\text { BDCA-2, BDCA-3, and } \\
\text { BDCA-4 antigens }\end{array}$ & & Dendritic cells & Identifies subsets of dendritic cells & (3) \\
\hline BENE & $17 \mathrm{kDa}$ & Endothelium & $\begin{array}{l}\text { "Raft-associated" member of MAL family; } \\
\text { interacts with caveolin-1 }\end{array}$ & (4) \\
\hline CMRF-44 & $?$ & Dendritic cells & Differentiated/activated & $(5,6)$ \\
\hline CMRF-56 & $95 \mathrm{kDa}$ & Dendritic cells & Differentiated/activated & \\
\hline H47 antigen & $\begin{array}{l}100 \mathrm{kDa} \text { (non } \\
\text { red.) } 120 \mathrm{kDa} \\
\text { (red.) }\end{array}$ & $\begin{array}{l}\mathrm{T} \text { cells \& most NK and B cells and } \\
\text { monocytes }\end{array}$ & ? Involved in T-cell activation & (7) \\
\hline Hal-1 & 200 kDa (100 kDa) & $\begin{array}{l}\text { T cells, EBV-transformed B cells, } \\
\text { myelo-monocytic cells, anaplastic } \\
\text { large cell lymphoma }\end{array}$ & ? New lymphoma marker & (8) \\
\hline LAK1 and LAK2 antigens & $\begin{array}{l}120 \mathrm{kDa} \text { and } 110 \\
+140 \mathrm{kDa} \\
\text { respectively }\end{array}$ & LGL and LAK cells & & (9) \\
\hline NKp80 & 80-kDa dimer & NK cells and CD56-positive T cells & $\begin{array}{l}\text { Novel member of the killer cell lectin-like } \\
\text { receptor gene family, encoded by } \\
\text { KLRF1 gene; triggers NK cell } \\
\text { cytotoxicity }\end{array}$ & $(10,11)$ \\
\hline $\begin{array}{l}\text { VAP-1 (vascular adhesion } \\
\text { protein) }\end{array}$ & $90 \mathrm{kDa}$ & Endothelium & $\begin{array}{l}\text { Mediates lymphocyte-endothelial } \\
\text { adhesion; has monoamine oxidase } \\
\text { activity }\end{array}$ & $(12,13)$ \\
\hline Wue-1 antigen & $94 \mathrm{kDa}$ & Plasma cells & Stimulates growth of plasma cells & (14) \\
\hline \multicolumn{5}{|l|}{ Identified by gene cloning } \\
\hline B-cell maturation factor & 184 aa & B cells & $\begin{array}{l}\text { TNFR family member; receptor for TALL- } \\
1 \text { and APRIL }\end{array}$ & $(15,16)$ \\
\hline B7-H2 & 302 aа & Dendritic cells & $\begin{array}{l}\text { New member of B7 family; binds ICOS on } \\
\text { activated T cells }\end{array}$ & $(17)$ \\
\hline CLEC-1 & 280 aа & Dendritic cells & $\begin{array}{l}\text { Novel C-type lectin-like receptor with } \\
\text { cytoplasmic tyrosine-based motif }\end{array}$ & (18) \\
\hline CMRF-35A & 224 aа & NK cells, neutrophils, monocytes, & Novel Ig superfamily receptors; CMRF- & $(19,20)$ \\
\hline CMRF-35H & 300 aа & $\begin{array}{l}\text { dendritic cells, and subset of } \mathrm{T} \\
\text { lymphocytes }\end{array}$ & $\begin{array}{l}35 \mathrm{H} \text { contains } 3 \text { cytoplasmic tyrosine } \\
\text { based motifs }\end{array}$ & \\
\hline $\mathrm{CS} 1$ & & NK cells & $\begin{array}{l}\text { Novel receptor belonging to CD2 subset } \\
\text { of Ig superfamily }\end{array}$ & $(21)$ \\
\hline DC-STAMP & 470 aa & Dendritic cells & $\begin{array}{l}\text { Novel protein containing seven putative } \\
\text { transmembrane domains. }\end{array}$ & $(22)$ \\
\hline EMR3 & 652 aа & $\begin{array}{l}\text { Mainly leukocyte restricted. } \\
\text { Highest levels on neutrophils, } \\
\text { monocytes, and macrophages }\end{array}$ & $\begin{array}{l}\text { Novel EGF-TM7 molecule; interacts with } \\
\text { a surface ligand on myeloid cells }\end{array}$ & (23) \\
\hline Flt-1 (VEGFR-1) & & Endothelial cells, monocytes & & $(24)$ \\
\hline GPRv53 & 390 aа & Leukocytes & $\begin{array}{l}\text { Identified by gene cloning; G-protein- } \\
\text { coupled histamine receptor }\end{array}$ & (25) \\
\hline IRTA1 and IRTA2 & & Subpopulations of B cells & $\begin{array}{l}\text { Homologous to the Fc and inhibitory } \\
\text { receptor families }\end{array}$ & (26) \\
\hline M160 & 1453 aа & Macrophages & $\begin{array}{l}\text { New member of scavenger receptor } \\
\text { cysteine-rich superfamily }\end{array}$ & $(27)$ \\
\hline $\begin{array}{l}\text { MARCO (macrophage } \\
\text { receptor with collagenous } \\
\text { structure) }\end{array}$ & 520 aа & Macrophages & $\begin{array}{l}\text { Class A scavenger receptor; involved in } \\
\text { bacterial clearance in vivo }\end{array}$ & $(28,29)$ \\
\hline TACI & 293 aa & B cells & $\begin{array}{l}\text { TNFR family member; receptor for TALL- } \\
1 \text { and APRIL }\end{array}$ & $(30)$ \\
\hline $\begin{array}{l}\text { TREM-1 and TREM-2 } \\
\text { (triggering receptors expressed } \\
\text { on myeloid cells) }\end{array}$ & & $\begin{array}{l}\text { Neutrophils and subset of } \\
\text { monocytes (TREM-1) and } \\
\text { macrophages (TREM-2) }\end{array}$ & $\begin{array}{l}\text { Novel Ig superfamily receptors; TREM-1 } \\
\text { triggers neutrophil secretion (e.g., IL- } \\
\text { 8) and degranulation; TREM-2 } \\
\text { activates macrophages, and both } \\
\text { associate with DAP12 }\end{array}$ & $(31,32)$ \\
\hline
\end{tabular}

cells express cell surface proteins found on leukocytes and vice versa (e.g., CD56, CD100, CD168, CD171). Furthermore, the guidance cues used by neuronal cells share similarities to those involved in leukocyte extravasation, so the expression of these molecules in common may reflect shared biological processes. It may also be noted that other mole- cules such as the mucins, thought to be primarily associated with epithelial cells, are now being described on leukocytes.

Finally, it remains to be established how the 8th and subsequent HLDA Workshops should deal with lineage- or stage-restricted leukocyte molecules that are localized within the cell cytoplasm (or nucleus). 
Given the importance of many of these molecules in signaling pathways initiated via known surface CD molecules, their identification and study is an inevitable extension of the work of the first seven HLDA Workshops. Whether or not a new "intracellular CD" categorization scheme is devised for such molecules, they are of interest for many laboratories studying human hematopoietic cells, and their investigation will be among the aims of the next Workshop.

\section{REFERENCES}

1. André P, Biassoni R, Colonna M, Cosman D, Lanier LL, Long $\mathrm{EO}$, et al. New nomenclature for MHC receptors. Nat Immunol 2001;2:661.

2. Zeng L, Takeya M, Takahashi K. AM-3K, a novel monoclonal antibody specific for tissue macrophages and its application to pathological investigation. J Pathol 1996;178:207-14.

3. Dzionek A, Fuchs A, Schmidt P, Cremer S, Zysk M, Miltenyi S, et al. BDCA-2, BDCA-3, and BDCA-4: three markers for distinct subsets of dendritic cells in human peripheral blood. J Immunol 2000;165:6037-46.

4. de Marco MC, Kremer L, Albar JP, Martinez-Menarguez JA, Ballesta J, Garcia-Lopez MA, et al. BENE, a novel raftassociated protein of the MAL proteolipid family, interacts with caveolin-1 in human endothelial-like ECV304 cells. J Biol Chem 2001;276:23009-17.

5. Hock BD, Starling GC, Daniel PB, Hart DN. Characterization of CMRF-44, a novel monoclonal antibody to an activation antigen expressed by the allostimulatory cells within peripheral blood, including dendritic cells. Immunology 1994;83:573-81.

6. Hock BD, Fearnley DB, Boyce A, McLellan AD, Sorg RV, Summers KL, et al. Human dendritic cells express a $95 \mathrm{kDa}$ activation/differentiation antigen defined by CMRF-56. Tissue Antigens 1999;53:320-34.

7. Hirohashi N, Nakao M, Kubo K, Yamada A, Shichijo S, Hara A, Sagawa K, et al. A novel antigen (H47 Ag) on human lymphocytes involved in $\mathrm{T}$ cell activation. Cell Immunol 1993;152:371-82.

8. Asanuma H, Takahashi S, Ishikawa M, Kamiguchi K, Sato N, Poppema S, et al. A monoclonal antibody, 3G12, reacts with a novel surface molecule, Hal-1, with high expression in CD30-positive anaplastic large cell lymphomas. Br J Haematol 1999;106:55-63.

9. Zocchi MR, Poggi A, Mariani S, Gianazza E, Rugarli C. Identification of a new surface molecule expressed by human LGL and LAK cells production of a specific monoclonal antibody and comparison with other NK/LAK markers. Cell Immunol 1989;124:144-57.

10. Vitale M, Falco M, Castriconi R, Parolini S, Zambello R, Semenzato G, et al. Identification of NKp80, a novel triggering molecule expressed by human NK cells. Eur J Immunol 2001;31:233-42.

11. Roda-Navarro P, Arce I, Renedo M, Montgomery K, Kucherlapati R, Fernandez-Ruiz E. Human KLRF1, a novel member of the killer cell lectin-like receptor gene family: molecular characterization, genomic structure, physical mapping to the NK gene complex and expression analysis. Eur J Immunol 2000;30:568-76.

12. Bono P, Salmi M, Smith DJ, Jalkanen S. Cloning and characterization of mouse vascular adhesion protein-1 reveals a novel molecule with enzymatic activity. J Immunol 1998;160: 5563-71.

13. Salmi M, Jalkanen S. A 90-kilodalton endothelial cell molecule mediating lymphocyte binding in humans. Science 1992;257:1407-9.
14. Greiner A, Neumann M, Stingl S, Wassink S, Marx A, Riechert $\mathrm{F}$, et al. Characterization of Wue-1, a novel monoclonal antibody that stimulates the growth of plasmacytoma cell lines. Virchows Arch 2000;437:372-9.

15. Madry C, Laabi Y, Callebaut I, Roussel J, Hatzoglou A, Le Coniat M, et al. The characterization of murine BCMA gene defines it as a new member of the tumor necrosis factor receptor superfamily. Int Immunol 1998;10:1693-702.

16. Shu HB, Johnson H. B cell maturation protein is a receptor for the tumor necrosis factor family member TALL- 1 . Proc Natl Acad Sci U S A 2000;97:9156-61.

17. Wang S, Zhu G, Chapoval AI, Dong H, Tamada K, Ni J, et al. Costimulation of $\mathrm{T}$ cells by B7-H2, a B7-like molecule that binds ICOS. Blood 2000;96:2808-13.

18. Colonna M, Samaridis J, Angman L. Molecular characterization of two novel C-type lectin-like receptors, one of which is selectively expressed in human dendritic cells. Eur J Immunol 2000;30:697-704.

19. Jackson DG, Hart DN, Starling G, Bell JI. Molecular cloning of a novel member of the immunoglobulin gene superfamily homologous to the polymeric immunoglobulin receptor. Eur J Immunol 1992;22:1157-63.

20. Green BJ, Clark GJ, Hart DN. The CMRF-35 mAb recognizes a second leukocyte membrane molecule with a domain similar to the poly Ig receptor. Int Immunol 1998;10:891-9.

21. Boles KS, Mathew PA. Molecular cloning of CS1, a novel human natural killer cell receptor belonging to the CD2 subset of the immunoglobulin superfamily. Immunogenetics 2001;52:302-7.

22. Hartgers FC, Vissers JL, Looman MW, van Zoelen C, Huffine C, Figdor CG, et al. DC-STAMP, a novel multimembranespanning molecule preferentially expressed by dendritic cells. Eur J Immunol 2000;30:3585-90.

23. Stacey M, Lin HH, Hilyard KL, Gordon S, McKnight AJ. Human epidermal growth factor (EGF) module-containing mucin-like hormone receptor 3 is a new member of the EGF-TM7 family that recognizes a ligand on human macrophages and activated neutrophils. J Biol Chem 2001;276: 18863-70.

24. Sawano A, Iwai S, Sakurai Y, Ito M, Shitara K, Nakahata T, et $a l$. Flt-1, vascular endothelial growth factor receptor 1 , is a novel cell surface marker for the lineage of monocytemacrophages in humans. Blood 2001;97:785-91.

25. Oda T, Morikawa N, Saito Y, Masuho Y, Matsumoto S. Molecular cloning and characterization of a novel type of histamine receptor preferentially expressed in leukocytes. J Biol Chem 2000;275:36781-6.

26. Hatzivassiliou G, Miller I, Takizawa J, Palanisamy N, Rao PH, Iida S, et al. IRTA1 and IRTA2, novel immunoglobulin superfamily receptors expressed in B cells and involved in chromosome 1q21 abnormalities in B cell malignancy. Immunity 2001;14:277-89.

27. Gronlund J, Vitved L, Lausen M, Skjodt K, Holmskov U. Cloning of a novel scavenger receptor cysteine-rich type I transmembrane molecule (M160) expressed by human macrophages. J Immunol 2000;165:6406-15.

28. Elomaa O, Sankala M, Pikkarainen T, Bergmann U, Tuuttila A, Raatikainen-Ahokas A, et al. Structure of the human macrophage MARCO receptor and characterization of its bacteria-binding region. J Biol Chem 1998;273:4530-8.

29. van der Laan LJ, Dopp EA, Haworth R, Pikkarainen T, Kangas $\mathrm{M}$, Elomaa O, et al. Regulation and functional involvement of macrophage scavenger receptor MARCO in clearance of bacteria in vivo. J Immunol 1999;162:939-47.

30. Xia XZ, Treanor J, Senaldi G, Khare SD, Boone T, Kelley M, et $a l$. TACI is a TRAF-interacting receptor for TALL-1, a tumor necrosis factor family member involved in B cell regulation. J Exp Med 2000;192:137-43. 
31. Bouchon A, Dietrich J, Colonna M. Cutting edge: inflammatory responses can be triggered by TREM-1, a novel receptor expressed on neutrophils and monocytes. J Immunol 2000; 164:4991-5.
32. Daws MR, Lanier LL, Seaman WE, Ryan JC. Cloning and characterization of a novel mouse myeloid DAP12associated receptor family. Eur J Immunol 2001;31: 783-91.

\section{Errata}

In the Modern Pathology November article "Immunohistochemical Detection of the Alternate INK4a-Encoded Tumor Suppressor Protein p14 ${ }^{\mathrm{ARF}}$ in Archival Human Cancers and Cell Lines Using Commercial Antibodies: Correlation with p16 ${ }^{\text {INK4a }}$ Expression" by Joseph Geradts, M.D., Robb E. Wilentz, M.D., and Helen Roberts, B.Sc. (Mod Pathol 2001:14(11):1162-1168), the title was misprinted. The error was corrected before the article was posted to the Internet.

In the Modern Pathology December article "Immunohistochemical Analysis of RCAS1 in Human Pituitary Adenomas," author Takeshi Watanabe's name was misspelled. 